\title{
Teachers' Attitudes to Syrian Refugee Students in Turkey
}

\author{
Semih Ekin ${ }^{a} *$ (D), Ramazan Yetkin ${ }^{a}$ \\ ${ }^{a}$ Hacettepe University, Ankara, 06800, Turkey
}

Received 18 January 2021

Received in revised form 1 March 2021

Accepted 22 March 2021

APA Citation: Ekin S., \& Yetkin, R. (2021). Teachers' attitudes to Syrian refugee students in Turkey. Eurasian Journal of Applied Linguistics, 7(1), 383-396.

Doi: $10.32601 /$ jal.911458

\begin{abstract}
From the last decade on, the matter of refugees in Turkey has become a key issue in almost all social and political areas including education. Following the refugee influx from 2011 on, Turkey has immediately taken action to provide the Syrian refugee students with necessary educational opportunities in its mainstream schools. The present study was targeted at revealing Turkish teachers' attitudes towards these Syrian refugee students in their classrooms. A total of 95 in-service teachers from different fields participated in the study. The data were collected through a composite instrument. Teachers' attitudes were categorized under three main subheadings; communication, adaptation, and efficiency. The statistical results indicated that the teachers were eager to help the refugee students overcome their adaptation problems which were mainly caused by their language-related deficiencies. They also had positive attitudes to communicate effectively with these students although they did not have enough practice in their undergraduate years in regards with the refugee education. Moreover, the teachers with high efficacy beliefs had better attitudes toward refugee students in their classrooms. The results were discussed in line with the refugee education and teacher education policies in the literature.
\end{abstract}

(C) 2021 EJAL \& the Authors. Published by Eurasian Journal of Applied Linguistics (EJAL). This is an open-access article distributed under the terms and conditions of the Creative Commons Attribution license (CC BY-NC-ND) (http://creativecommons.org/licenses/by-nc-nd/4.0/).

Keywords: Refugee; refugee education; migration; teacher attitude; Syrian refugees

\section{Introduction}

Throughout the centuries, people have faced to change their geographical position either by force or for the aspiration of a brighter future. As defined by Parry (2019) in Britannica Encyclopedia, immigration is the practice by which people have become a part of another country. People are displaced mainly for economic reasons; however, the number of refugees displaced through conflict cannot be underestimated. Turkey as it is located among Europe, Asia, and Africa, has always become a center route for immigrants. As being also located in the core of wars in the middle east since 2000 such as Iraqi war, war in Afghanistan, Russian-Georgian war, Syrian civil war, and

\footnotetext{
* Corresponding author.

E-mail address: ekinsemih@gmail.com

http://dx.doi.org/10.32601/ejal.911458
} 
Russian- Ukrainian conflicts, Turkey has always kept its gatekeeper role in the international immigration movements. Refugees enforced to depart their home countries for different reasons such as fight and war (Refugee Council, 2016) form the main immigration movements towards Turkey. According to The UN Refugee Agency (hereafter UNHCR) report (2019), Turkey is home to almost 4 million refugees who are mainly Syrians (3.6 million) forced to leave their countries due to Syrian civil war from 2011 on. The state level policies have firstly provided the core needs like nutrition and security for these refugees. Afterwards, the integration of those who were in schooling age into the education was of prime importance (Aydın, Gündoğdu \& Akgül, 2019). That's why, some organizational and educational steps were taken and lots of Syrian refugee students were provided learning environments. This process entails some affordances and challenges which should be examined to get insights for different contexts which is why the current study tried to conceptualize the situations of refugees in Turkey with regard to schooling and in-service teacher attitudes towards these students. The was mainly formulated to investigate following research questions:

1. What are the teachers' attitudes toward the refugee students in terms of their communication and adaptation and how do they see the undergraduate teacher training about refugee education?

2. What are the teachers' own ideas about their efficacy toward the refugee students?

3. Do the teachers with low/middle and high self-efficacy in terms of the refugee students differ from each other about the refugee students' communication and adaptation process?

\section{Review of Literature}

\subsection{Refugees and Their Influx to Turkey since Millennium}

Immigration is a broad term that encompasses both human or animal movement across the geographies. It can come out through different reasons such as economical, educational, and obligatory due to several mandatory reasons like wars. There are key differences between a migrant and a refugee even though they are mostly used interchangeably. A migrant is someone who deliberately leaves his/her home to look for a bright future. The migrants can make necessary preparations like seeking information, language and employment opportunities. They are also able to come back home (Refugee Council, 2016). On the contrary, a refugee refers to the individual enforced to leave his/her home due to life risks. Refugees' main apprehensions are their life safety not economic reasons. They mostly leave all their belongings such as homes, families, friends, and all of their staff behind (Refugee Council, 2016). To this end, approaching the refugees in terms of providing social opportunities is quite different to the migrants. The situation may force the governments to take abrupt 
actions when there is a refugee influx; however, they can be ready for a controlled migrant influx.

Due to ongoing conflicts and war occurring mostly around Turkey as mentioned above, the influx of refugees to Turkey has extraordinarily increased due to the beginning of the Syrian civil war. From 2011 on, an unexpected number of refugee flows to Turkey was observed. According to a recent report released by Refugees Association (2020), there are officially almost 3.6 million Syrians currently living in Turkey.

\subsection{Refugees and Education in Turkey}

Education is an universal human right and needs to be met by all the governments. According to Turkish National Education Basic Law of 1739, education (k-12) is both free and obligatory for all the citizens. Refugees, similarly, have been included to this long-standing order since they have left everything behind already. According to the official numbers (Refugees Association, 2020), almost 47\% of the Syrian refugees are under 18 years old. Similarly, the number of children in this refugee group is estimated to be at least 1.7 million (Bircan, \& Sunata, 2015), and a total of 450000 Syrian babies were estimated to be born in Turkey during the civil war. In these regards, education for the Syrians was seen as key and crucial by the Turkish authorities. Much research also indicated that integration of Syrian refugee students into main education system is very much vital and required (Aydın et al., 2019; Bircan \& Sunata, 2015). To this end, government created different educational opportunities for these students in a dual system both for students living in the camps and living out of camps (Alpaydin, 2017). Many educational structures such as public schools, camp education centers, temporary education centers (Taşkin \& Erdemli, 2018) and many other local initiatives such as informal schools where Syrian teachers willingly teach (Bircan \& Sunata, 2015) were created to give large body of opportunities to these students. Inclusively, an education campaign has also been started titled "Project on promoting integration of Syrian kids into the Turkish education" (hereafter PIKTES) in order to specifically focus on refugee students' education needs and requirements. The scope and purpose of the PIKTES, according to their declaration, is

"Promoting Integration of Syrian Kids into the Turkish Education System (PIKTES)" is an education project implemented by the Ministry of National Education with a view to contribute to the access of children under Temporary Protection to education. PIKTES is funded by a direct EU grant within the scope of the "Facility for Refugees in Turkey (FRIT)" agreement. The Project was launched on October 3, 2016, and it still is in operation in 26 provinces. PIKTES Project, which started its second phase in December 2018, will continue until the end of 2021 (n.d.).

By the help of the nationwide PIKTES project and the other similar initiatives, the initial educational step was taken to integrate the Syrian students into the learning environments by actively engaging both Turkish and Syrian teachers. Therefore, the 
refugee students' adaptation process and social cohesion was aimed at easing via the help from their Syrian teachers and they were prepared for a new learning environment which is Turkish Education system via the help from the Turkish teachers (PIKTES). These students, after this preliminary educational support, were directed to mainstream state schools to integrate with their Turkish peers and to follow their compulsory k-12 education. After all, this whole process was aimed at equipping the refugee students with Turkish and Arabic language and the other content knowledge that they will need in their future education similar to their Turkish peers.

\subsection{Studies of Teacher Views on Refugees' Education in Turkey}

After the arrival of the Syrian refugees to Turkey and their inclusion to education system, many educators have begun to discuss this process. To this end, many studies have already been conducted in the literature. Turkey is a very good sample for these studies in understanding the refugees, especially in today's world. Most of these studies have yielded similar results and brought about common problems faced by teachers and Syrian refugee students. Considering these results, language problems (Başar, Akan, \& Çiftçi, 2018; Kardeş \& Akman, 2018; Kiremit, Akpınar, \& Akcan, 2018; Şahin \& Sümer, 2018; Tösten, Toprak, \& Kayan, 2017), adaptation problems (Başar et al., 2018; Kardeş \& Akman, 2018; Toker-Gökçe \& Acar, 2018; Uzun \& Bütün, 2016), teacher adaptation (Sağlam \& Kanbur, 2017; Kiremit et al., 2018) and teacher competence (Kardeş \& Akman, 2018; Şahin \& Sümer, 2018) were found to be the key issues and problems put forward by the teachers. Some other minor problems were also revealed such as disruption (Kiremit et al., 2018), overcrowded classrooms (Tösten, et al., 2017), and lack of equipment (Şahin \& Sümer, 2018). It was also found that people, in general, do not have negative attitudes toward Syrians (Çiftçi, 2018), and that teachers who have Syrian children in their classroom have better attitudes than those teachers who do not have any Syrian children in their classrooms (Sağlam \& Kanbur, 2017). Reviewing the literature, it can be concluded that the changing societal problems and the integration process of the Syrian refugee students necessitate the researchers to examine these students and their teachers in different intervals to keep the track of the quality education and adaptation. The current study, therefore, is aimed at understanding the views of teachers who currently have Syrian children in their classrooms.

\section{Method}

\subsection{Methodological Framework}

This study was designed as a quantitative and descriptive research. Quantitative research mainly focuses on the variables to obtain information about the objective theories (Creswell, 2013). Quantitative research studies try to associate the variables by setting some cause-and-effect relationships. Some important characteristics of quantitative research have been suggested by Dörnyei (2007) as the generalizability, 
the big sample size, statistical analysis, and previously set hypothesis. Firstly, the quantitative studies are expected to elicit more generalizable data because they include a lot of participants. The data are based on the numbers, and they are analyzed through the statistical analysis. They are ungrounded and the researchers generally have a hypothesis before conducting a research. One of the most common ways to conduct a quantitative research is the survey method which is used for "numeric descriptions of trends, attitudes, or opinions of a population by studying a sample of that population" (Creswell, 2013, p. 145). Most of the survey research is employed by using questionnaires, because they can be easily managed by delivering big size groups at one time which provide the researchers to make implications for a general population by analyzing a smaller and specific sample (Dörnyei, 2007; Sukamolson, 2007).

\subsection{Setting and the Participants}

This study was conducted via a scale. The participants were selected by using a snowball sampling procedure. Snowball sampling was defined as accessing the participants by the help of the other participants engaged in the study and it has been one of "the most widely employed method of sampling in qualitative research" (Noy, 2008, p. 330). Therefore, the participants were from different parts of Turkey working in different institutions. All of the teachers in the study work at either state schools or universities. In state schools and universities, there are lots of Syrian refugees who are scattered in the classrooms so that they can adapt to the other students. For example, there are almost 4 or 5 Syrian refugee students in each class of the state schools and they are expected to get education with the mainstream education program in Turkey. By this way, it is aimed at adapting the refugee students in a better way. The participants of the study were 95 teachers. 79 of them were female and 16 of them were male. The participants were also from different departments; 27 of them were English language teachers, 30 of them were classroom teachers, and 37 of them were from the other departments (Physics, Math, Biology etc.). The teachers were mostly novice, and they had 1 to 10 years of experience $(\mathrm{N}=88)$. There were also some more experienced teachers who have more than 10 years of experience $(\mathrm{N}=7)$. The participants differed also in terms of their educational background. 80 of them had undergraduate degrees, and 15 of them had an MA or $\mathrm{PhD}$ degree.

\subsection{Instruments}

The study employed a scale titled Refugee Student Attitude Scale, which was developed by Sağlam and Kanbur (2017) to get insights from the teachers about their refugee students' attitudes towards different parameters. The instrument has 24 fourpoint Likert-scale items. The scale has three sub-dimensions which were communication (11 items), adaptation (9 items), and efficiency (4 items) together with some demographic questions (gender, year of experience etc.). The scale was originally in Turkish. In the communication sub-dimension of the scale, the items were related 
to how the teachers approach and communicate with the refugee students and there were items like "I try to understand the refugee students" or "I communicate with the refugee students without prejudice". In the adaptation sub-dimension, the items concerned about how the refugee students and the other students adapt to each other, the teachers, and the school environment etc. Sample items for this dimension were "The refugee students are adapted to the school" or "The students are happy with the existence of the refugee students in the school". The last sub-dimension was about how the teachers regard themselves in terms of efficacy and how they are competent about teaching and communicating with the refugee students. Sample items for this variable were "I ease the refugee students' adaptation process into the school environment" and "I think I am efficient enough to teach the refugee students". The Cronbach's Alpha reliability coefficients for the variables in Sağlam and Kanbur's study (2017) were communication $(\alpha=.88)$, adaptation $(\alpha=.88)$, and efficacy $(\alpha=.80)$. The current study's Cronbach's Alpha reliability coefficients were also at a satisfactory level; communication $(\alpha=.87)$, adaptation $(\alpha=.76)$, and efficacy $(\alpha=.70)$. There was also an evaluation question about whether the teachers think that the refugee education practices were enough or not in their undergraduate years and they answered this question as either "yes" or "no".

\subsection{Data Collection and Analysis}

The data was collected through an online scaling process. The scale was prepared on an online document and a link to this document was created. This link was shared by using a purposeful sampling process. The participants were informed beforehand about the study. The questionnaire was only shared with the participants who wanted to participate in the study. After the data collection procedure, the data was entered to SPSS 25 to conduct the analysis statistically. First of all, the data was checked in terms of normality and linearity. Although Kolmogorov-Smirnov and Shapiro-Wilk tests suggested significant results, further analysis on Q-Q plots showed that the data was normally distributed. Therefore, we went on analysis via the use of parametric tests. For the first and second research questions, the descriptive analysis was conducted. For the third research question, a multivariate analysis of variance was done to examine the differences among the teachers with low, middle, or high selfefficacy beliefs in terms of their attitudes towards the refugee students' communication and adaptation process.

\section{Results and Discussion}

What are the teachers' attitudes toward the refugee students in terms of their communication and adaptation and how do they see the undergraduate teacher training about refugee education?

The study's main aim is to investigate the general tendencies of the teachers' attitudes towards the refugee students' communication and adaptation process. Therefore, a descriptive analysis was run to see what they think about the refugee 
students. In the data sample, there were normally 95 participants; however, 66 teachers have had an experience with the refugee students. Thus, the descriptive analysis was run by these teachers who have had an experience with the refugee students to elicit more reliable results.

Table 1. The Descriptive Statistics for Communication and Adaptation Variables

\begin{tabular}{llll}
\multicolumn{2}{l}{ Table 1. The Descriptive Statistics for Communication and Adaptation Variables } & \multicolumn{2}{c}{$S D$} \\
\hline Communication & $n$ & 3.28 & .50 \\
Adaptation & 66 & 2.45 & .43 \\
\hline
\end{tabular}

The results (Table 1) suggested that the teachers mostly think that they and the refugee students have a high level of communication $(M=3.28, S D=.50)$. On itembased analysis, the highest scored item was "I regard and act the refugee students the same as my other students" ( $M=3.50, S D=.63)$. However, the lowest scored item was "I develop myself in terms of the refugee students' education and training." $(M=2.86$, $S D=.87)$. What we can infer from this preliminary result is that the teachers' thoughts about their communication with their refugee students are at a satisfactory level and this can be also the reason why they do not want to develop their pedagogical knowledge about these students. This situation can be regarded as an unwanted process in teacher development because the teachers are expected to develop their communication competences to become better than good in different aspects (Bower, Cavanagh, Moloney \& Dao, 2011).

As for the adaptation of the refugee students to the school environment, it can be claimed that the teachers may have some doubts about this issue and the scores were generally ranging from moderate to low $(M=2.45, S D=.43)$. The highest scored item for this variable was "I try to guide and help the refugee students" $(M=3.20, S D=$ .70). The lowest scored item was "The parents of the mainstream students have positive attitudes towards the refugee students" $(M=2.06, S D=.74)$. According to the results, most of the teachers think that the refugee students have some adaptation problems to the school environment. The lowest scoring item also tells us much about how the parents and the elder ones evaluate the adaptation of the refugee students. They may see the refugees as a debilitating factor for their children's education process.

Through frequency analysis, the evaluation question about whether the teachers think that their undergraduate training about the refugee student education is enough or not had striking results. We wanted to include all of the participants in this report, because they all are graduates of a teacher training program and this report is expected to reflect a general framework about refugee education in pre-service teacher education program. The results suggested that the teachers do think that their undergraduate practices were not enough in their undergraduate years (Enough; $n=$ 3 , Not Enough; $n=92$ ). We are aware of the limitation of a question eliciting a general understanding about a phenomenon, but the number of the participants and the proportion of the results can be considered as a convincing result for all the stakeholders to revisit the teacher education program and practices about the refugee and 
immigrant students' education. It is also important that when thinking about the circumstances where "teachers have not been prepared to support the success of refugees" (p. 442) and to feel incompetent, we can witness more critical situations in the following educational experiences of these students and teachers which makes the problem deeper and requires action for the teachers all over the world (Gagné, Schmidt \& Markus, 2017).

What are the teachers' own ideas about their efficacy toward the refugee students?

Another important aspect of the study was to investigate how teachers regard themselves in terms of dealing with the refugee students and how effective they were. This was tested by analyzing the third component of the scale which was "efficacy". The descriptive analysis was run to examine the situation.

Table 2. The Descriptive Statistics for Teachers' Efficacy Scores

\begin{tabular}{llll}
\hline & $n$ & $M$ & $S D$ \\
\hline Efficacy & 66 & 2.55 & .58 \\
\hline
\end{tabular}

The results (Table 2) suggested that although the teachers think that their communication with the refugee students is high, their efficacy in terms of dealing with them seems moderate $(M=2.55, S D=.58)$. When analyzing the items, the lowest score was given to the item 24 "The refugee students' different language is not a problem for me." $(M=2.15, S D=.98)$. This result may imply that most of the teachers have problems related to language which makes the feel inefficient in terms of dealing with the refugee students. The refugee students mostly do not know Turkish, and they try to adapt the school environment like an immersion program. The communication breakdowns and pedagogic incompetence that can be experienced by the teachers may mostly be because of the language problems according to this result. This result has also been documented as one of the most important problems of teachers currently (Aydın \& Kaya, 2017; Toker-Gokçe \& Acar, 2018). The highest score was given to item 21 "I try to ease the refugee students' adaptation to the classroom." ( $M=3.12, S D=.71)$. This result may be important to understand the efforts of the teachers in the classroom. Although they have some problems with the refugee students in terms of language differences, they try to help them in the classroom and they take actions in the schools by setting up support rooms, orientation process and parental help (Toker-Gokçe \& Acar, 2018).

Do the teachers with low/middle and high self-efficacy in terms of the refugee students differ from each other about the refugee students' communication and adaptation process?

The teachers were grouped into three as the teachers with low efficacy, middle efficacy, and high efficacy according to their efficacy scores. Then they were analyzed whether there are significant differences among them in terms of their communication and adaptation attitudes. The main aim in this research question is to investigate whether there is an effect of efficacy perception on the teachers' attitudes toward the refugee students. First of all, the descriptive analysis was shared below. 
Table 3. The scores of the teachers with Low, Middle and High Efficacy

\begin{tabular}{|c|c|c|c|c|c|c|}
\hline & \multicolumn{3}{|c|}{ Communication } & \multicolumn{3}{|c|}{ Adaptation } \\
\hline & Low & Middle & High & Low & Middle & High \\
\hline$n$ & 27 & 28 & 11 & 27 & 28 & 11 \\
\hline$M$ & 2.99 & 3.40 & 3.69 & 2.14 & 2.60 & 2.81 \\
\hline$S D$ & .48 & .44 & .28 & .38 & .33 & .30 \\
\hline
\end{tabular}

According to the results (Table 3), the communication scores were different among the teachers with low efficacy $(M=2.99, S D=.48)$, middle efficacy $(M=3.40, S D=$ $.44)$, and high efficacy $(M=3.69, S D=.28)$. Adaptation scores were also different among low efficacy $(M=2.14, S D=.38)$, middle efficacy $(M=2.60, S D=.33)$, and high efficacy groups $(M=2.81, S D=.30)$. To understand whether these differences were statistically significant or not, a one way between groups multivariate analysis of variance (MANOVA) was conducted.

Table 4. Results for the Teachers in terms of Their Communication and Adaptation Scores

\begin{tabular}{|c|c|c|c|c|}
\hline & Wilks' $\Lambda$ & $F(4,124)$ & $p$ & Partial eta ${ }^{2}$ \\
\hline $\begin{array}{l}\text { Communication and } \\
\text { Adaptation }\end{array}$ & .586 & 9.500 & .000 & .235 \\
\hline
\end{tabular}

The results (Table 4) suggested that there were statistically significant differences among three groups in terms of their communication and adaptation scores Wilks' $\Lambda=$ $.586, F(4,124)=9.500, \mathrm{p}=.000$, partial eta squared $=.235$. The further analysis was to investigate the pairwise comparisons among the groups.

Table 5. Pairwise Comparisons of Communication and Adaptation Scores of the Teachers

\begin{tabular}{|c|c|c|c|c|}
\hline & $F(2,66)$ & $p$ & Partial eta ${ }^{2}$ & Group Differences \\
\hline Communication & 11.703 & .000 & .271 & $\begin{array}{l}\text { Low }<\text { Middle, } p=.003 \\
\text { Low }<\text { High, } p=.000 \\
\text { Middle }<\text { High, } p=.181\end{array}$ \\
\hline Adaptation & 19.284 & .000 & .380 & $\begin{array}{l}\text { Low }<\text { Middle, } p=.000 \\
\text { Low }<\text { High, } p=.000 \\
\text { Middle }<\text { High, } p=.284\end{array}$ \\
\hline
\end{tabular}

The results suggested that the teachers with a low efficacy thought their communication was also low at a statistically significant level when they were compared with the teachers with middle and high efficacy (also see Table 3). However, there was not a significant difference between the teachers with middle and high efficacy in terms of their communication with the refugee students. Adaptation attitudes also yielded similar results with the communication. The teachers with low 
efficacy thought that the refugee students have a bad adaptation process. Their scores were significantly lower than the teachers with middle and high efficacy. However, there was not a significant difference between the teachers with middle and high efficacy in terms of their adaptation attitudes towards the refugee students (see Table $3)$.

As understood from the Table 4, teachers' self-efficacy beliefs made significant attitude differences towards refugee students and higher self-efficacy beliefs are likely to ease their teaching process in these multilingual/multicultural classes. Of the previous studies, the results of the both Er and Bayındir (2015), and Kubilay and Kılıç (2019) studies indicated that majority of teachers feel incompetent (low selfefficacy beliefs) in teaching multicultural situations and they expect to see pending problems if they teach in these environments. In a study in German primary and secondary level inclusive education context, teachers were grouped into self-efficacy dimension groups (curriculum development, classroom management and cooperation) regarding their implementation of inclusive education. Study results indicated that while positive self-efficacy leads to implementation of inclusion in the greatest way, teachers with low efficacy ends up with the lowest level of implementation of inclusion (Kiel, Braun, Muckenthaler, Heimlich, \& Weiss, 2019).

\section{Conclusion}

This study was conducted to present what the current educational situation is from the teachers' perspectives who have refugee students in their classrooms. The study was designed around teachers' views and attitudes towards Syrian students in their classrooms primarily, motivated through communication and adaptation variables and teachers' efficacies. The results mainly suggested that the teachers have a high level of communication with the refugee students. It was seen that teachers are eager to communicate with their Syrian students, and there is no barrier for communication breakdowns among teachers and students despite language barrier was seen as the key problem of education process in some previous studies (e.g. Taşkin \& Erdemli, 2018). As seen in Sağlam and Kanbur's (2017) work presenting that teachers having refugee students in their classes had better feelings than other teachers. Similarly, in the present study, it was seen that teachers are eager to see and deal with refugee students in their teaching environment. The other part of the research question was discussed in the implications part which has relation to how the teachers regard their refuge education in their undergraduate years.

Teachers also think that the refugee students have some adaptation problems. According to results, refugee students' language problems and novel environment were the main driving force in the adaptation problems. In the previous studies, language problems (e.g. Başar et al., 2018) and adaptation problems (e.g. Kardeş \& Akman, 2018) were the highly reported problems faced by teachers. However, the present study indicated that teachers did not see adaptation problems as debilitating, and they were willing to help those students to overcome it. Because many of those 
students were born in a foreign country with a different mother tongue and they currently have little knowledge of medium of instruction language (Turkish), their adaptation problems are likely to get easier over time with the attainment of the target language and adaptation to new environment and their friends.

The third research question may imply that the lower a teacher's efficacy is, the worse he or she may think his/her communication with the refugee students is or the worse the adaptation process of the refugee students is. This result is quite important because there may be a relationship between the teachers' self-efficacy understandings and their communication and adaptation attitudes towards the refugee students. If the teacher can feel more efficient, his/her ideas may change, and he/she may think that "I can communicate with my refugee students in a better way", or "I can help the adaptation of the refugee students more". However, if he/she feels inefficient, it may be a blockage or a prejudice that hinders himself/herself from better communication with the refugee students. The teacher with a low efficacy may also think that the refugee students may not be able to adapt to the school environment and he/she cannot help them. Therefore, this may imply that a change in the teacher identity especially in such a delicate situation may help him/her overcome the difficulties more easily.

\section{Implications for Teacher Education and Suggestions for Further Research}

The present study was primarily designed to find out teachers' views and attitudes to Syrian refugee students in their classroom. Overall, it was detected that teachers had positive feelings toward refugee students in the classrooms though they needed some training on it because they are not mainly trained to cope with problems raised by refugee students in their classes (Aydin, et al., 2019). They presented good communication with those students and their adaptation problems were not considered as a barrier to education by teachers. However, teachers' self-efficacy beliefs made statistically significant differences in their attitudes to Syrian students. Teachers regarding themselves as not competent enough presented lower scores and this result may also have an effect on their overall ideas about school environment and especially the motivation in the teaching contexts. Considering the earlier research focusing on teacher motivation and career motivation (e.g. Ekin, Yetkin, \& Öztürk, 2021; Topkaya \& Uztosun, 2012), it can be asserted that the pre-service teachers generally have a satisfactory level of motivation, especially in Turkish context. However, the efficacy result in the current study brings some insights about what can happen in the real classroom environment when becoming an in-service teacher. Therefore, the policies should be adapted to keep this motivation and efficacy understanding in both pre-service and in-service teachers durable even in different circumstances (i.e. refugee student education in this sense) by giving training, preparing them for the refugee students in their classrooms, and providing resources to ease their problems. 
In line with these research questions, the study suggested an important phenomenon with the evaluation question. The teachers claimed in the study that they had good communication and adaptation with the refuge students. However, they also think that they did not have enough training and practice about refuge education in their undergraduate years. This is an important problem that all the policy-makers need to think about. The refugee issue is not peculiar to Turkey, but it is an international one. Therefore, the undergraduate programs should be enriched with the refugee education, the pre-service teachers should be trained about how they are going to deal with these groups of students, how they can establish mutual understanding, and how they can teach effectively. Otherwise, the education programs leave this problem to the teacher's own capability which may lack in a professional sense.

This study is a descriptive study with a quantitative nature. Further studies using mix-method research design can draw more depth insights into the phenomenon. Furthermore, including refugee students' views on their education and comparing these views with teachers' data may reveal valuable information on the current problems on refugee education. Lastly, studies with experimental designs comparing teachers by specific training with refugee students to teachers with no training can bring new insights into the refugee student education.

\section{The Research and Publication Ethics Statement}

In this study, the data were collected by receiving the consent and the written forms from all of the participants. Throughout the study, there was no violation of ethical considerations.

\section{The Conflict of Interest Statement}

In line with the statement of Committee on Publication Ethics (COPE), we hereby declare that I/we had no conflicting interests regarding any parties of this study.

\section{References}

Alpaydin, Y. (2017). An Analysis of Educational Policies for School-Aged Syrian Refugees in Turkey. Journal of Education and Training Studies, 5(9), 36-44.

Aydin, H., Gundogdu, M., \& Akgul, A. (2019). Integration of Syrian refugees in Turkey: Understanding the educators' perception. Journal of International Migration and Integration, 20(4), 1029-1040

Aydin, H., \& Kaya, Y. (2017). The educational needs of and barriers faced by Syrian refugee students in Turkey: A qualitative case study. Intercultural Education, 28(5), 456-473.

Başar, M., Akan, D., \& Cịftçi, M. (2018). Multeci ögrencilerin bulunduğu sinıflarda ögrenme sürecinde karșlașlan sorunlar. Kastamonu Education Journal, 26(5), 1571-1578. doi:10.24106/kefdergi.427432

Bircan, T., \& Sunata, U. (2015). Educational assessment of Syrian refugees in Turkey. Migration Letters, 12(3), 226-237. 
Bower, M., Cavanagh, M., Moloney, R., \& Dao, M. (2011). Developing communication competence using an online Video Reflection system: pre-service teachers' experiences. Asia-Pacific Journal of Teacher Education, 39(4), 311-326.

Çiftçi, H. (2018). Türkiye Cumhuriyeti vatandaşlarının Suriyeli sığınmacılara yönelik tutum, algı ve empatik eğilimlerinin analizi. İnsan ve Toplum Bilimleri Araştırmaları Dergisi, 7(3), $2232-2256$.

Creswell, J. W. (2013). Research design: Qualitative, quantitative, and mixed methods approaches. California, CA: Sage publications.

Dörnyei, Z. (2007). Research methods in applied linguistics: Qualitative, quantitative and mixed methodologies. Oxford, UK: Oxford University Press.

Ekin, S., Yetkin, R. \& Öztürk, S. Y. (2021). A Comparative study of career motivations and perceptions of student teachers. Turkish Studies - Education, 16(1), 505-516. https://dx.doi.org/10.47423/TurkishStudies.47210

Er, A. R., \& Bayındır, N. (2015). Pedagogical approaches of elementary teachers for primary refugee children. International Journal of Social and Educational Sciences, 2(4), 175-185. https://doi.org/10.20860/ijoses.08223

Gagné, A., Schmidt, C., \& Markus, P. (2017). Teaching about refugees: Developing culturally responsive educators in contexts of politicised transnationalism. Intercultural Education, 28(5), 429-446.

Ivankova, N. V., Creswell, J. W., \& Stick, S. L. (2006). Using mixed-methods sequential explanatory design: From theory to practice. Field Methods, 18(1), 3-20.

Kardeş, S., \& Akman, B. (2018). Suriyeli sığınmacıların eğitimine yönelik öğretmen görüşleri. Elementary Education Online, 17(3), 1224-1237.

Kiel, E., Braun, A., Muckenthaler, M., Heimlich, U., \& Weiss, S. (2020). Self-efficacy of teachers in inclusive classes. How do teachers with different self-efficacy beliefs differ in implementing inclusion?. European Journal of Special Needs Education, 35(3), 333-349.

Kiremit, R.F., Akpınar, U:, \& Tưfekçi Akcan, A. (2018). Suriyeli ögrencilerin okula uyumları hakkında ögretmen görüssleri. Kastamonu Egĭtim Dergisi, 26(6), 2139-2149. doi:10.24106/kefdergi.428598

Kubilay, S., \& Kiliç, R. (2019). Awareness Level and Self-Efficacy Beliefs of Pre-Service Primary School Teachers Regarding Syrian Students' Education in Turkey. Asian Journal of Education and Training, 5(1), 248-254.

Noy, C. (2008). Sampling knowledge: The hermeneutics of snowball sampling in qualitative research. International Journal of Social Research Methodology, 11(4), 327-344.

Parry, S. (2019). Immigration. Encyclopedia Britannica. Retrieved from https://www.britannica.com/topic/immigration

Promoting Integration of Syrian Kids into the Turkish Education System (n.d.). About PIKTES. https://piktes.gov.tr/Home/IndexENG

Sağlam, H. İ., \& İlksen-Kanbur, N. (2017). Investigation attitudes towards refugee students of class teachers' in terms of several variables. Sakarya University Journal of Education, 7(2), $310-323$.

Sahin, S., \& Sümer, S. (2018). The problems experienced in the integration process of Syrian students into the Turkish education system. Universal Journal of Educational Research, 6(5), 909-918.

Sukamolson, S. (2007). Fundamentals of quantitative research. Language Institute, Chulalongkorn University. Retrieved from http://www.culi.chula.ac.th/Research/eJournal/bod/Suphat\%20Sukamolson.pdf

Tashakkori, A., \& Creswell, J. W. (2007). The new era of mixed methods research [Editorial]. Journal of Mixed Methods Research, 1, 3-7. 
Taskin, P., \& Erdemli, O. (2018). Education for Syrian refugees: Problems faced by teachers in Turkey. Eurasian Journal of Educational Research, 18(75), 155-178.

Toker Gokce, A., \& Acar, E. (2018). School Principals' and Teachers' Problems Related to the Education of Refugee Students in Turkey. European Journal of Educational Research, 7(3), 473-484.

Topkaya, E. Z., \& Uztosun, M. S. (2012). Choosing teaching as a career: Motivations of preservice English teachers in Turkey. Journal of Language Teaching and Research, 3(1), 126-134.

Tösten, R., Toprak, M., \& Kayan, M. S. (2017). An Investigation of Forcibly Migrated Syrian Refugee Students at Turkish Public Schools. Universal Journal of Educational Research, 5(7), 1149-1160.

Turkey: Key facts and figures (2019, November). The UN Refugee Agency Turkey. Retrieved April 3, 2020, from https://www.unhcr.org/tr/unhcr-turkiye-istatistikleri

Türkiye’deki Suriyeli Sayısı (2020, March 26). Refugees Association. Retrieved April 1, 2020, from https://multeciler.org.tr/turkiyedeki-suriyeli-sayisi/

Uzun, E. M., \& Bütün, E. (2016). Okul öncesi eğitim kurumlarındaki Suriyeli sığınmacı çocukların karşılaştıkları sorunlar hakkında öğretmen görüşleri. Uluslararası Erken Çocukluk Eğitimi Çalışmaları Dergisi, 1(1), 72-83.

Who is a refugee? Who is an asylum seeker? (2016, February 16). Refugee Council of Australia. Retrieved April 7, 2020, from https://www.refugeecouncil.org.au/definitions/

\section{Copyrights}

Copyright for this article is retained by the author(s), with first publication rights granted to the Journal.

This is an open-access article distributed under the terms and conditions of the Creative Commons Attribution license (CC BY-NC-ND) (http://creativecommons.org/licenses/by-nc-nd/4.0/). 